\title{
ATTITUDE OF EMPLOYEES ON THE APPLICATION AND SIGNIFICANCE OF HACCP SYSTEM IN RURAL TOURIST HOUSEHOLDS IN SERBIA DURING COVID-19
}

Tamara Gajić ${ }^{1}$, Jovanka Popov Raljićn ${ }^{2}$ Slobodan Čerović ${ }^{3}$, Milica Aleksić ${ }^{4}$, Višnja Sikimić ${ }^{5}$

*Corresponding author E-mail: tamara.gajic.1977@gmail.com

A R T I C L E I N F O

Original Article

Received: 05 April 2021

Accepted: 01 December 2021

doi:10.5937/ekoPolj2104929G

UDC 338.48-44(1-22):[616-

$036.22+578.834](497.11)$

338.486.2-57: [316.644:006.83]

\section{Keywords:}

rural households, food safety, HACCP, Covid-19, Republic of Serbia

JEL: I12, J28, L83, O18, Q18

\begin{abstract}
A B S T R A C T
Diseases caused by food consumed in restaurants during a pandemic, can cause enormous damage and lead to closure of rural households. The aim of the research was to determine the attitude of employees in rural households on the application and importance of doing business according to the HACCP (Hazard Analysis and Critical Control Point) food safety system in 47 rural tourist households in Serbia during the COVID-19 pandemic. A structured field survey questionnaire was conducted on a sample of 286 employees. The generated data were processed by the statistical program Statistica 14.0. The obtained results show that the application of HACCP food safety system during the pandemic was highly appreciated by the employees and that operating according good hygiene practice (GHP) and good manufacturing practice (GMP) fully meets all safety requirements and the extent to which employees in rural households must be aware of and be instructed in its application.
\end{abstract}

(C) 2021 EA. All rights reserved.

1 Tamara Gajić, PhD, associate professor, Faculty of Tourism and Hotel Management, Singidunum University, Belgrade, Senior Researcher, Department of the Tourism and Socio-Cultural Service at the Institute of Sport, Tourism and Service, South Ural State University, Chelyabinsk, Russia. Phone: 063565544, E-mail: tamara.gajic.1977@gmail. com, ORCID ID (https://orcid.org/0000-003-3016-8368)

2 Jovanka Popov Raljić, PhD, full professor, Faculty of Tourism and Hotel Management, Singidunum University, Belgrade, Phone: 063 8366966, E-mail: jpopov@singidunum. ac.rs, ORCID ID (https://orcid.org/0000-0003-4910-1286)

3 Slobodan Čerović, PhD, dean, full professor, Faculty of Tourism and Hotel Management, Singidunum University, Belgrade, E-mail: scerovic@singidunum.ac.rs, ORCID ID (https:// orcid.org/0000-0002-4646-2476)

4 Milica Aleksić, PhD, Assistan Professor, University of Business Studies, Banja Luka. Phone: 064 2227331, E-mail: aleksic.milica75@gamil.com, ORCID ID (https://orcid. org/0000-0002-8565-9749)

5 Višnja Sikimić, PhD, professor, Academy of Technical Vocational Studies, Belgrade (ATSSB)., Phone. 063 8193668, E-mail: visnja.sikimic@gmail.com, ORCID ID (https:// orcid.org/0000-0002-5189-7909)

http://ea.bg.ac.rs 


\section{Introduction}

Hospitality activities in rural households are very complex and specific, in terms of introducing sustainable systems and procedures related to food safety and quality, given the different dynamics of the process of preparation, production, storage and serving of food (Chen et al., 2020). According to the data of the Republic Bureau of Statistics, in the Republic of Serbia, rural tourism as an activity is recognized in 50 villages with about 3.000 beds (Gajić et al., 2018). About $85 \%$ of the total territory of Serbia is occupied by rural areas where over $40 \%$ of the total population lives. There are 4.709 settlements in Serbia, i.e villages (according to the Constitution, there is no category of villages), and 1.200 are in the phase of disappearance, which has less than 50 inhabitants (Gajić et al., 2018; Cvijanović \& Gajić, 2021). Consumers have a right to expect their food to be safe, of good quality and fit for consumption. In that sense, food safety and quality on the international market are of great importance. Properly planned, managed, financially monitored and implemented HACCP system, is a model that will contribute to the safety of service users, improve their health, and thus customer satisfaction (Trafialek \& Kolanowski, 2017). In the Republic of Serbia, the Law on Food Safety (Official Gazette of RS, 41/2009 and 17/2019) and the Rulebook on General and Special Conditions of Food Hygiene at Any Stage of Production, Processing and Trade (Official Gazette of RS, 72/2010 and 62/2018), defines that all entities in the food business must establish a system for ensuring food safety, in accordance with the principles of good production and hygiene practice, and hazard analysis and critical control points (HACCP). The application of HACCP system in rural catering in relation to the food industry is related to the fact that the key difference is the existence of a large number of input and final products, numerous complex recipes, technology of individual production of different products in a small space and additional food serving (Aleksić et al., 2020, World Food Programme, 2020). Rural catering is specific in terms of providing healthy food, which would achieve a high level of quality (Gajić et al., 2020a). The COVID-19 pandemic that emerged in 2019. imposed enormous consequences, including economic losses and threats to human health, which continue to affect many aspects around the world (Han et al., 2021). The Food and Agriculture Organization (FAO, 2020) stated that COVID-19 affects agriculture in two key ways, in terms of food supply and demand, which are directly related to food safety (Gossling et al., 2020). The food supply chain is a link that connects agricultural systems with end consumers of food through processes related to production, packaging, distribution and storage (Quevedo-Leon et al., 2020). Similar research on food safety during the COVID-19 pandemic was conducted worldwide in 2020 (Xiang et al., 2020). In their research, entitled Impacts of the COVID-19 pandemic on consumers food safety knowledge and behavior in China, they developed an econometric model technique for assessing knowledge and behavior about food safety of residents. The results of a survey conducted on a sample of 1.373 people in China show that residents who focus on food safety information also practice different behaviors regarding proper nutrition. Further, they point out that the COVID-19 pandemic improves food safety knowledge and influences behavior, while the focus on available food safety information is an important 
mechanism for improving behavior. Also, in all facilities of their research, the application of the food protection and safety system was at a high level (Xiang et al., 2020).

The obtained results can contribute to the social and scientific research sector, when it comes to COVID-19, and its mode of transmission, as well as the identification of all strategic measures to combat pandemics in food and accommodation facilities. If each country achieves similar results, a shift could be expected, at least in the domain of understanding that COVID-19 is not transmitted through food if all Safety System measures are implemented. The practicality of the research can also be of fundamental importance, in order to acquire new knowledge about the business system in food safety in rural households, and the effective fight against the penetration of the pandemic through this area. The significance of this paper is reflected in the contribution of the results from the area of Serbia, because there is no similar research on a given topic from this area. The limitations in the research were certainly related to the social distance and approach, as well as the will of the respondents to fill in the surveys, as well as, of course, the limited working hours of the catering facilities. The main limitation of this and similar research is the absence of universally defined indicators and parameters that describe individual components of HACCP implementation policy in rural households.

\section{Literature review}

Some of the characteristics and consequences of Covid 19 on the tourism and hospitality sector

COVID 19, appeared suddenly and crashed all over the planet (Carlos et al., 2020). About 50.000 people have lost their jobs in Serbia since March 2020. Predictions are, and it is now quite certain, that economic growth everywhere in the world will be significantly lower than planned (Gajić et al., 2020a; 2020b). Some branches of the economy are extremely hard hit and the question is how long it will take them to recover. In such a new situation, the only logical solution was to close a large number of hotels in Serbia, because due to low demand, it is not rational to keep the employed infrastructure, when variable costs are significantly higher than current business inflows (Cvijanović \& Gajić, 2021). The facilities were preserved in the second half of March, workers were sent on collective vacations, and shifts were organized, which supported the measure of social distancing. First of all, the drop in traffic this year alone by $55 \%$ to $70 \%$, in hotels brings with it a large drop in non-board consumption. Currently, according to the data from the last quarter of 2019, about 83.140 employees work in the hospitality industry in Serbia, and as a consequence, we can expect a drop in employment of $60 \%$ with an additional drop in average salaries of 35\% (Cvijanović \& Gajić, 2021).

\section{Food safety and COVID 19}

Based on current knowledge and risk assessment regarding the outbreak and spread of coronavirus disease (COVID-19), there is no evidence to suggest that the virus is transmitted through food, as the host (human or animal) is required for coronavirus transmission (Qui et al., 2020; Lin et al., 2020). The primary ways in which the virus 
is transmitted is from person to person, close contacts, as well as staying in a space with a large number of people (Abudllah et al., 2004; Pine \& Mckercher, 2004). Corpet (2021), in his research claims that SARS, stays on the carton for 24 hours, two days on stainless steel and three days on polypropylene (plastic). Traces of the Corona virus were reportedly found in China on packages of frozen shrimp and chicken wings imported from South America (Assaf et al., 2020; Du Bois, 2020). The question of whether the Corona virus is transmitted through the packaging of frozen food has once again come to the public's attention (Elgin et al., 2020). The demands of today's buyer of a rural tourist product are increasing, and they are especially expressed in terms of food safety (Ahuja \& Sicherer, 2007). In the dynamics of the product finalization process, a high frequency of health risks is expressed. Namely, there is a large number of products and processes that are performed during food preparation and where the food comes into contact with various equipment and surfaces, with an emphasis on the constant presence of employees who manipulate food (Dzwolak, 2017). HACCP (Hazard Analysis and Critical Control Points) is a food safety system based on the analysis and control of potential biological, chemical and physical hazards to which raw materials are exposed, possible hazards during handling, production, distribution and consumption of the final product (Taylor, 2008; Fotiadis et al., 2021). Fresh agricultural products in rural households are grown, not always, in hygienic environments, and people, water and animals are the main dangers in agriculture (Bas et al., 2007; Baker et al., 2020; PopovRaljić \& Blešić, 2021). A special danger is created with fresh products, which are considered in rural households as organic, which do not go through further processing (Kampf et al., 2020). The modern approach to food safety is a comprehensive system of so-called food safety chain "from field to table" based on risk analysis (Hecht et al., 2019; Principato et al., 2021). Rural tourist households as well as other catering facilities, have a key role to play in ensuring adequate application of applicable regulations and producing food that does not endanger the health of consumers (Gibson et al., 2012). Among the legal changes in 2009, the Republic of Serbia introduced a new Law on Food Safety (Official Gazette of RS, 41/2009 and 17/2019) which requires the application of a food safety system based on the principle of hazard analysis of critical control points (HACCP -Hazard Analysis and Critical Control Point) for all entities in the food chain except primary production.

Olaimat et al., (2020), in their study entitled Food Safety During and After the Era of COVID-19 Pandemic, claim that there is no specific data on the retention of Covid virus on food packaging, except for other viruses and bacteria. They further point out that the implementation of food safety management systems such as Hazard Analysis and Critical Control Points (HACCP) are very important in reducing the risk of Covid infection. Jawed et al., (2020) point out that HACCP-based nutrition systems are not as effective as desired in reducing pandemic risk. They also argue that other elements should be added to the HACCP food safety system: food safety, food quality, food defense and food fraud. They suggest changes in the food safety system. regulation on food hygiene (852/2004) specifies the obligation to set up an HACCP plan in 
one's company to fight against consumer-related hazards. The HACCP plan must be regularly updated, for example, in response to changes in recipes or processes. The current context has led businesses to review their HACCP plan(s). The HACCP plan is one of the elements of the SCP (Sanitary Control Procedures). Its update is not a regulatory obligation. It is a choice of the company, but it is necessary in the context of the Covid-19 crisis (Guide 2020 edition - COVID-19 update).

H1: Employees in rural households or hosts consider there is no difference observed in application of HACCP food safety system principles, before and during the Covid-19 pandemic.

$\mathrm{H} 2$ : There is no statistically significant difference in the application of the Food Safety System in rural households that are HACCP certified, and those that do not have a certificate.

H2a: There is a statistically significant difference in the application of the Food Safety System in rural households that are HACCP certified, and those that are not certified.

H3: There is a statistically significant difference in operations of rural households that apply only GHP and GMP, from those that have HACCP certification.

H4: There is a statistically significant difference in the attitudes of the respondents about the influence of the responsible person on the application of HACCP.

\section{Methodology}

Sampling During 2020, for 5 months (from June to October), a field survey was conducted using a modified structured survey questionnaire (Ahuja \& Sicherer,2007; Sharma, 2011; Soon, 2018) on a total of 286 respondents who were employed in 47 rural tourist households in rural areas of Serbia (in Vojvodina - 18 households, Central Serbia - 10, Western Serbia -12 and Eastern Serbia - 7). The structured questionnaire contained two parts, where the first part included a demographic description of the respondents, while the second part contained questions related to the implementation and views on the HACCP food safety system in rural tourist households during the Covid-19 pandemic. The authors of the paper went to the field, to rural households and whitewashed their answers. Some household owners, or employees, completed the questionnaires themselves, while the authors took care to reduce ambiguities during the survey, in order to obtain complete answers.

\section{Instruments}

As stated, a modified questionnaire was used. The questions were asked and evaluated on the basis of a five-point Likert scale (with grades from 1- strongly, 2 - disagree, 3- undecided, 4 - agree, 5- strongly agree). The obtained results were statistically processed using the statistical program Statistica 14.0 (Dell Inc., 2020). Dell Statistica is a general purpose analytics work bench that allows users to access, prepare, analyze, report and deploy advanced analytical models within vendor agnostic 
environments. Statistics 14.0 is a major release, with new features and functionalities, better performance and an interface (Soon, 2018). Descriptive statistical analysis is presented, which usually precedes statistical inference and prediction, but can also be the ultimate goal of statistical analysis. Depending on the target group of subjects, they were analyzed using the $\chi 2$ (chi-square) test to determine the statistical significance of differences between the distribution of respondent responses. In the processing of the obtained data, the standard measure of central tendency - arithmetic mean (Xsr), measure of variability - standard deviation $(\mathrm{Sd})$, distribution asymmetry coefficient - skewness (Sk), distribution form coefficient (flatness or elongation) - kurtosis (Ku) were used. Since all variables are normally distributed, parametric statistics methods were used. The marginal level of statistical significance is expressed at the level of probability 0.05 . Generally speaking, the instrument shows satisfactory measuring characteristics. Reliability was determined by the Crombach alpha coefficient. The internal reliability of the questionnaire used is 0.80 (Krombach's alpha coefficient $\alpha=0.897$, with standardization $\alpha=0.873$ ). The obtained values of the standardized skewness and kurtosis indicators are in the ranges of acceptable limit values asymmetry $<1 \mid$; homogeneity $<|3|$ ), which indicates that adequate parametric methods can be applied in the processing of the results.

\section{Results and Discussions}

In terms of demographic indicators, it can be stated that in the sample, despite a slightly higher share of women among respondents compared to men (55\% vs. 45\%), respondents of both sexes were evenly represented. In terms of age, the survey predominantly (over $90 \%$ ) included respondents of younger age categories (up to 45 years), while the share of those older than 45 years is slightly above $7 \%$. The obtained data indicate that a negligible number of respondents with completed primary school participated in the survey, the most represented were respondents with completed secondary school (50\%), and a significant share of respondents with completed higher education or academic studies $(42 \%)$. The share of respondents with completed postgraduate studies is relatively small $(7 \%)$. The sample has a dominant share (over $80 \%$ ) of facilities engaged in organic production and food and beverage services. Food business operators are obliged to establish a food safety system at all stages of food production, processing and trade, except at the level of primary production, in accordance with the principles of Good Manufacturing Practice (GMP) and Good Hygienic Practice - GHP) and hazard analysis and critical control points (HACCP) (Popov-Raljić \& Blešić, 2012; 2016). The basis of the food safety system to be adopted in catering is a combination of preconditions / standard operating procedures for sanitation (SSOP) / good hygiene practice (GHP), then, good manufacturing practices (GMP) and food safety system, ie - hazard analysis and critical control points (HACCP) (Oliveira et al., 2016; Popov-Raljić \& Blešić, 2021).

The obtained data indicate that in rural households of Serbia, according to employees, the application of HACCP system is at a relatively high level, given that the degree of application of procedures necessary for the functioning of HACCP system was rated 
high, over 4. The claim is that business according to HACCP is not changed compared to the previous period and time during Covid-19, thus confirming the initial hypothesis H0. A slightly lower grade was found for the receipt of food from the supplier due to insufficient precision compliance with the maintenance of the required temperature during transport and delivery of the necessary documentation $(\mathrm{Xsr}=3.92 ; \mathrm{Sd}=0.71$; $\mathrm{Cv}=18.04)$. Contrary to the above, the highest score was recorded for an important segment - intake of fresh fruits and vegetables and sensory quality (appearance-color; smell and taste; texture $)(\mathrm{Xsr}=4.44 ; \mathrm{Sd}=0.78 ; \mathrm{Cv}=17.53)$ and regular monitoring, and recording the temperature in the premises intended for storage $(\mathrm{Xsr}=4.39 ; \mathrm{Sd}=$ $0.70 ; \mathrm{Cv}=15.97)$. Temperature control when receiving and storing food is extremely important, if frozen food is used in a rural household because there is a greater risk of bacteria and spoilage for food thawed at room temperature, so the best way to safely thaw, for example: meat, poultry and fish meat in the refrigerator; using a microwave oven or immersing in hygienically correct cold water (Lateefat, et al., 2018).

Similar values were obtained when answering the question regarding inventory and tools used for processing food of different origin (animal / vegetable) (Xsr = 4.04), while statistical data processing showed variation $(\mathrm{Sd}=1.22 ; \mathrm{Cv}=30.31)$, which indicates possible occasional omissions in rural households when handling certain tools and inventory (for example, the use of the same knives, the same board). When it comes to the attitudes of respondents related to the business of rural households on the principles of good hygiene (GHP) and good manufacturing practice (GMP), as well as the application of HACCP, the average values of all answers are at a very high level $(\mathrm{Xsr} \approx 4.50)$. The results of all aspects of HACCP application in rural tourist households during the pandemic (Table 1), except for verification of evidence of maintenance of required transport temperature and all necessary documentation at reception, indicate similar distributions of responses: the vast majority of respondents rated consistency 4 or 5. HACCP operations in rural tourist households contribute to better sustainable food safety and quality - generally observed during the Covid 19 pandemic, which was confirmed by the results of the survey $(\mathrm{Xsr}=4.36 ; \mathrm{Sd}=0.73 ; \mathrm{Cv}=16.67)$.

Table 1. Descriptive indicators of the perception of the application of the HACCP system in rural households by employees in Serbia during the Covid-19 pandemic.

\begin{tabular}{|l|c|c|c|}
\hline $\begin{array}{l}\text { PERCEPTION OF APPLICATION OF HACCP DURING } \\
\text { A PANDEMIC }\end{array}$ & $\boldsymbol{X}_{s r}$ & $\boldsymbol{S}_{\boldsymbol{d}}$ & $\boldsymbol{C}_{v}$ \\
\hline $\begin{array}{l}\text { When receiving food from the supplier, you require proof of } \\
\text { maintaining the required temperature in transport and all the necessary } \\
\text { documentation }\end{array}$ & 3,92 & 0,71 & 18,04 \\
\hline $\begin{array}{l}\text { When receiving fresh fruits and vegetables, you sensory control and } \\
\text { evaluate the quality }\end{array}$ & 4,44 & 0,78 & 17,53 \\
\hline $\begin{array}{l}\text { Foods that do not meet the requirements prescribed by the HACCP } \\
\text { system upon receipt are returned to your supplier }\end{array}$ & 4,28 & 0,71 & 16,71 \\
\hline $\begin{array}{l}\text { Regularly monitor and record the temperature in the rooms intended for } \\
\text { storage }\end{array}$ & 4,39 & 0,70 & 15,97 \\
\hline
\end{tabular}




\begin{tabular}{|c|c|c|c|}
\hline $\begin{array}{l}\text { PERCEPTION OF APPLICATION OF HACCP DURING } \\
\text { A PANDEMIC }\end{array}$ & $X_{s r}$ & $S_{d}$ & $C_{v}$ \\
\hline $\begin{array}{l}\text { Keep regular records of maintaining the hygiene of work surfaces and } \\
\text { premises in which food is processed and stored according to established } \\
\text { procedures }\end{array}$ & 4,33 & 0,66 & 15,35 \\
\hline Use the same boards to process foods of different origins (animal, plant) & 4,04 & 1,22 & 30,31 \\
\hline $\begin{array}{l}\text { Use the same knives to process food of different origins (animal, } \\
\text { vegetable) }\end{array}$ & 4,00 & 1,12 & 28,04 \\
\hline $\begin{array}{l}\text { Ice machines and ice containers are cleaned and maintained according to } \\
\text { established procedures }\end{array}$ & 4,28 & 0,74 & 17,29 \\
\hline $\begin{array}{l}\text { Selectively dispose of waste from the kitchen block and bar and store in } \\
\text { appropriate containers at a temperature of } 0 \text { to }+5^{\circ} \mathrm{C}\end{array}$ & 4,25 & 0,91 & 21,48 \\
\hline \multicolumn{4}{|l|}{ ATTITUDES OF EMPLOYEES IN RURAL HOUSEHOLDS } \\
\hline $\begin{array}{l}\text { It is necessary that the rural tourist household has a standard recipe / } \\
\text { product description for each dish prepared in the kitchen block or a drink } \\
\text { prepared in the bar }\end{array}$ & 4,57 & 0,71 & 15,16 \\
\hline $\begin{array}{l}\text { It is necessary that the rural tourist household cooperates with accredited } \\
\text { laboratories that perform health testing of water, food and beverages }\end{array}$ & 4,46 & 0,75 & 16,85 \\
\hline $\begin{array}{l}\text { It is obligatory to keep records of preventive measures against rodents, } \\
\text { insects and other pests in the rural tourist household }\end{array}$ & 4,49 & 0,65 & 14,52 \\
\hline $\begin{array}{l}\text { In a rural tourist household, it is necessary to establish a system of } \\
\text { safe provision of food and beverage services in all phases of reception, } \\
\text { storage, processing and trade. }\end{array}$ & 4,51 & 0,66 & 14,58 \\
\hline $\begin{array}{l}\text { Operating according to the HACCP system contributes to better quality } \\
\text { operations of rural tourist households }\end{array}$ & 4,36 & 0,73 & 16,67 \\
\hline
\end{tabular}

Source: author's research

$* \mathrm{X}_{\mathrm{sr}}-$ Mean value, $\mathrm{sd}-$ Standard deviation, $\mathrm{C}_{\mathrm{v}}-$ Coefficient of variation

The results of examining the differences between the mean values of the answers obtained from the respondents engaged in rural tourist households applying good hygiene practice (GHP) and good manufacturing practice (GMP) showed a value of $p=0.02$ (less than $\mathrm{p}<0.05$ characteristic of $95 \%$ probability), which indicates that the application of good hygiene and manufacturing practices significantly affects the level of responses. When it comes to attitudes related to business practice and HACCP, no statistically significant differences were found between the answers of respondents engaged in facilities that apply GHP and GMP and those whose practice deviates from this rule (thus confirming hypothesis H2). The specific conditions in which rural households operate (limited financial and human resources, lack of knowledge on food safety management, etc.) indicate that certain elements of the security system (eg record keeping) are more difficult to implement than in medium and large enterprises., like the food industry (Dzwolak, 2017). When asked whether you keep regular records of maintaining the hygiene of work surfaces and premises in which the processing and storage of food in a rural household is performed, a statistically significant difference was found between the answers of respondents employed in rural households with HACCP certified and respondents employed in households they do not have certified HACCP. The obtained 
value $\mathrm{p}=0.17$ (higher than $\mathrm{p}<0.05$ characteristic for $95 \%$ probability), indicates that HACCP certification does not significantly affect the level of responses obtained. When it comes to attitudes related to business practice and HACCP, respondents from rural households in which HACCP is certified rated their attitudes statistically significantly higher that doing business under the HACCP system contributes to the overall business of a rural tourist household (confirming hypothesis H3). Obtained results of testing the differences between the mean values of responses obtained from respondents engaged in rural households in which the person responsible for HACCP was appointed and those where the appointment was not made, a value of $\mathrm{p}=0.00$ (less than the significance threshold $\mathrm{p}<0.05$ characteristic of $95 \%$ probability), which indicates that the appointment of a responsible person (HACCP team leader) significantly affects the level of responses received. Table 2 . shows $\mathrm{p}$ values as indicators of probability that there are no statistically significant differences between the distributions of responses of different groups of respondents. All values less than 0.05 indicate a $95 \%$ probability that differences between different groups of respondents exist, and for values less than 0.01 the probability that differences exist is over $99 \%$.

Table 2. Probability of non-existence of differences in the distributions of respondents' responses depending on the perception of the application of the HACCP system in rural households in Serbia

\begin{tabular}{|l|l|l|l|l|l|l|}
\hline $\begin{array}{l}\text { PERCEPTION OF } \\
\text { APPLICATION OF HACCP } \\
\text { DURING A PANDEMIC }\end{array}$ & CS & $\begin{array}{l}\text { GHP } \\
\text { GMP }\end{array}$ & ARP & AT & CTR & TS \\
\hline $\begin{array}{l}\text { When receiving food from the } \\
\text { supplier, you require proof of } \\
\text { maintaining the required temperature } \\
\text { in transport and all the necessary } \\
\text { documentation }\end{array}$ & 0,7819 & 0,7340 & $\mathbf{0 , 0 1 0 4}$ & $\mathbf{0 , 0 0 6 5}$ & $\mathbf{0 , 0 3 1 7}$ & $\mathbf{0 , 0 0 7 1}$ \\
\hline $\begin{array}{l}\text { When receiving fresh fruits and } \\
\text { vegetables, you sensory control and } \\
\text { evaluate the quality }\end{array}$ & 0,4606 & 0,1848 & $\mathbf{0 , 0 2 2 5}$ & $\mathbf{0 , 0 0 0 2}$ & $\mathbf{0 , 0 0 0 2}$ & $\mathbf{0 , 0 1 5 0}$ \\
\hline $\begin{array}{l}\text { You return food that does not meet } \\
\text { the requirements prescribed by the } \\
\text { HACCP system to your supplier } \\
\text { upon receipt }\end{array}$ & 0,3410 & $\mathbf{0 , 0 0 7 8}$ & $\mathbf{0 , 0 0 1 4}$ & $\mathbf{0 , 0 0 0 0}$ & $\mathbf{0 , 0 0 4 4}$ & $\mathbf{0 , 0 0 2 1}$ \\
\hline $\begin{array}{l}\text { Regularly monitor and record the } \\
\text { temperature in the rooms intended } \\
\text { for storage }\end{array}$ & 0,0981 & $\mathbf{0 , 0 0 4 4}$ & $\mathbf{0 , 0 0 0 9}$ & $\mathbf{0 , 0 0 0 0}$ & $\mathbf{0 , 0 0 0 4}$ & $\mathbf{0 , 0 0 0 1}$ \\
\hline $\begin{array}{l}\text { Keep regular records of maintaining } \\
\text { the hygiene of work surfaces and } \\
\text { premises in which food is processed } \\
\text { and stored according to established } \\
\text { procedures }\end{array}$ & 0,0507 & $\mathbf{0 , 0 0 9 7}$ & $\mathbf{0 , 0 0 1 0}$ & $\mathbf{0 , 0 0 1 4}$ & $\mathbf{0 , 0 0 0 8}$ & $\mathbf{0 , 0 0 2 9}$ \\
\hline $\begin{array}{l}\text { Ice machines and ice containers are } \\
\text { cleaned and maintained according to } \\
\text { established procedures }\end{array}$ & 0,0926 & $\mathbf{0 , 0 4 5 7}$ & $\mathbf{0 , 0 0 0 0}$ & $\mathbf{0 , 0 0 0 0}$ & $\mathbf{0 , 0 0 0 1}$ & $\mathbf{0 , 0 0 0 4}$ \\
\hline
\end{tabular}




\begin{tabular}{|l|l|l|l|l|l|l|}
\hline $\begin{array}{l}\text { PERCEPTION OF } \\
\text { APPLICATION OF HACCP } \\
\text { DURING A PANDEMIC }\end{array}$ & CS & $\begin{array}{l}\text { GHP } \\
\text { GMP }\end{array}$ & ARP & AT & CTR & TS \\
\hline $\begin{array}{l}\text { Selectively dispose of waste from } \\
\text { the kitchen block and bar and } \\
\text { store in appropriate containers at a } \\
\text { temperature of 0 to + 5 C }\end{array}$ & 0,7830 & 0,3662 & $\mathbf{0 , 0 0 0 1}$ & $\mathbf{0 , 0 0 0 0}$ & $\mathbf{0 , 0 0 0 3}$ & $\mathbf{0 , 0 0 3 2}$ \\
\hline $\begin{array}{l}\text { ATTITUDES OF EMPLOYEES } \\
\text { IN RURAL HOUSEHOLDS }\end{array}$ & & & & & & \\
\hline $\begin{array}{l}\text { It is necessary that the rural tourist } \\
\text { household has a standard recipe / } \\
\text { product description for each dish } \\
\text { prepared in the kitchen block or a } \\
\text { drink prepared in the bar }\end{array}$ & 0,4244 & 0,2755 & 0,3108 & 0,0113 & 0,3078 & 0,0666 \\
\hline $\begin{array}{l}\text { It is necessary that the rural } \\
\text { tourist household cooperates with } \\
\text { accredited laboratories that perform } \\
\text { health testing of water, food and } \\
\text { beverages }\end{array}$ & 0,3046 & 0,2116 & 0,6730 & 0,3019 & 0,5804 & 0,7233 \\
\hline $\begin{array}{l}\text { It is obligatory to keep records of } \\
\text { preventive measures against rodents, } \\
\text { insects and other pests in the rural } \\
\text { tourist household. }\end{array}$ & 0,3613 & 0,1724 & 0,8071 & 0,0676 & 0,6306 & 0,0411 \\
\hline $\begin{array}{l}\text { In a rural tourist household, it is } \\
\text { necessary to establish a system of } \\
\text { safe provision of food and beverage } \\
\text { services in all phases of reception, } \\
\text { storage, processing and trade. }\end{array}$ & 0,2343 & 0,0496 & 0,7972 & 0,1618 & 0,3931 & 0,0762 \\
\hline $\begin{array}{l}\text { Operating according to the HACCP } \\
\text { system contributes to better } \\
\text { quality operations of rural tourist } \\
\text { households }\end{array}$ & 0,0484 & 0,1671 & 0,4393 & 0,0489 & 0,1091 & $\mathbf{0 , 0 0 3 9}$ \\
\hline
\end{tabular}

Source: author's research

*CS- Certified HACCP system; GHP and GMP - Application of GHP and GMP; ARPAppointed responsible person; AT - Appointed HACCP team, CTR - Clear HACCP team responsibilities; TS - Trained staff.

Suppliers who deliver food of animal origin in addition to mandatory analyzes of microbiological safety (including toxicology), physico-chemical and sensory analysis must have a certified HACCP system, while rural households are not required to certify but must operate according to the principles of HACCP system (Popov-Raljić \& Blešić,2021). That the certified HACCP system does not significantly affect the level of the obtained responses was priced with the obtained value $p=0.17$ (which is significantly less than the value of $\mathrm{p}<0.05$ characteristic for $95 \%$ probability), which indicates the confirmation of hypothesis H1. The results indicate that there is no statistically significant difference in the application of the food safety system in rural tourist households that have a certified HACCP system and those that do not have a certificate, and the alternative hypothesis H1a was refuted. 
Previous research has also shown why there is a decline in tourist traffic in rural areas. Scott et al., (2020) in their research entitled How Does Household Spending Respond to an Epidemic? Consumption During the 2020 COVID-19 Pandemic, they indicated that as the number of cases grew, households began to radically change their typical consumption in a number of major categories. Principato et al., (2020), point out that a large amount of food waste is generated, due to improper management of food control and safety. In their study, Caring more about food: The unexpected positive effect of COVID -19 lockdown on household food management and waste, on a sample of 1.078 Italians, also pointed to some positive effects of the pandemic, as the largest percentage of respondents reduced the amount of throws food, and began to use food in households properly and in a controlled manner. A similar study was conducted by Han et al., (2021), who talk about the Covid-19 crisis and food safety. They point out that the pandemic has imposed huge consequences, including economic losses and threats to human health. They investigate the impact on the food supply system and food safety. The article highlights the effectiveness of food safety management after a pandemic. They also say that there is a possibility of foodborne infection, especially if the environment is unhygienic and does not operate according to appropriate safety standards.

\section{Conclusions}

The impact of COVID-19 around the world is primarily a human tragedy, which affects the health of hundreds of thousands of people, but has an increasing impact on both the global economy and the economy (Farzanegan et al., 2020). The aim of the research was to collect the opinion of employees in rural households, most of whom are also hosts of rural households that provide catering services. The aim was certainly not to highlight the results of the implementation of the HACCP system, before and after the pandemic, but to examine the attitude of employees on this issue. The goal of applying the HACCP principle in food retail and serving is for the operator to take appropriate measures to ensure safe and quality food (Garayoa et al., 2014). Food safety management should be fully integrated into the work as well as the actions taken during the business. With the spread of the COVID-19 pandemic, challenges related to food safety are in the focus of business of all food producers, catering facilities, but also rural tourist households (Shi et al., 2021). Due to the specific conditions in which small businesses operate as rural tourist households, elements of the food safety system are more difficult to implement than in medium and large companies (Dzwolak, 2014). During the COVID-19 pandemic, both in catering facilities and in rural tourist households, there were significant changes in behavior and an increase in the demand of food and beverage consumers for safe food and beverage service (Principato et al., 2021). The authors of the paper conducted field research in 47 rural households of the Republic of Serbia, on a total sample of 286 employees. A modified questionnaire Ahuja \& Sicherer (2007) was used; Sharma (2011) and Soon (2018). The obtained results were processed in the statistical software Statistica 14.0 (Dell Inc.,2020). After the analysis of the obtained data, the following can be concluded, which gives the answer to the set hypotheses: 
- There are no statistically significant differences in the answers of employees engaged in rural households in which the HACCP system is certified, and those in which this is not the case.

- Perception of respondents that the rural household in which they are engaged operates on the principles of good hygiene (GHP) and good manufacturing practice (GMP), affects that respondents at different levels perceive the application of different aspects of the HACCP system, than respondents in rural households where GHP and GMP do not apply, which is a logical conclusion, given the connection of the listed aspects of HACCP application with GHP and GMP.

- Perception of respondents that GMP and GHP are applied in the rural household does not affect the differences in respondents' attitudes towards HACCP.

- All aspects of HACCP implementation related to human resources, including appointment of a responsible person, appointment of HACCP team and clear differentiation of team members 'responsibilities, as well as training of HACCP staff, result in differentiation of HACCP implementation perception, but not differentiation of respondents' attitudes towards HACCP.

The paper can have a wide scientific, economic and social significance. Based on the obtained results, it is possible to determine the attitude of employees in rural households on the actual level of application of the HACCP safety system in rural catering facilities, and to contribute to similar research. The importance of the work contributes to the development of awareness among the employees about the adherence to the safety measures of the HACCP system, especially during the pandemic. Then the measures must be respected, and even expanded, as some authors claim. There were limitations in the persistence of epidemiological measures during the pandemic. Many facilities were closed during this period, so the sample is relatively small. However, the advantage of the survey is that the respondents were employees, who must be instructed in all food safety measures and in the workplace. The work related to the position on the application of the HACCP safety system is important due to the profile of the respondents, because tourists are certainly not informed about all existing measures, but they can notice if some key measures are not respected.

\section{Conflict of interests}

The authors declare no conflict of interest.

\section{References}

1. Abdullah, A., Thomas, G., McGhee, S., \& Morisky, D. (2004). Impact of severe acute respiratory syndrome (SARS) on travel and population mobility: Implications for travel medicine practitioners. Journal of Travel Medicine, 11(2), 107-111. DOI: https://doi.org/10.2310/7060.2004.17067. 
2. Ahuja, R., \& Sicherer, S. (2007). Food-allergy management from the perspective of restaurant and food establishment personnel. Annals of Allergy, Asthma and Immunology, 98, 344-348. DOI: 10.1016/S1081-1206(10)60880-0.

3. Aleksić, M., Popov-Raljić, J., Đorđević, V., Janković, V., Lukić, M., Rašeta, M., \& Spirić, D. (2020). Control of nutritive allergens in a hospitality kitchen. Meat Technology, 61 (1), 75-81. DOI: https://doi.org/10.18485/meattech.2020.61.1.7.

4. Assaf, A., \& Scuderi, R. (2020). COVID-19 and the recovery of the tourism industry. Tourism Economics, 26(5), 731-733. DOI: https: //doi.org/ 10.1177/ 1354816620933712

5. Baker, S., Farrokhnia, R.A., Meyer, S., Pagel, M., \& Zannelis, C. (2020). How Does Household Spending Respond to an Epidemic? Consumption During the 2020 COVID-19 Pandemic. The Review of Asset Pricing Studies, 10(4), 834-862.

6. Bas, M., Yüksel, M., \& Çavuooflu, T. (2007). Difficulties and barriers for the implementing of HACCP and food safety systems in food businesses in Turkey. Food Control, 18, 124-130. DOI: https://doi.org/10.1016/j.foodcont.2005.09.002.

7. Carlos, W. G., de la Cruz, C. S., Cao, B., Pasnick, S., \& Jamil, S. (2020). COVID-19 diseasendue to SARS-CoV-2 (novel coronavirus). American Journal of Respiratory and Critical Care Medicine, 201(4), 7-8. DOI: https://doi.org/10.1164/ rccm.2014P7.

8. Chen, S., Brahma, S., Mackay, J., Cao, C., \& Aliakbarian, B. (2020). The role of smart packaging system in food supply chain. Journal of Food Science, 85(3), $517-$ 525. DOI: https://doi.org/10.1111/1750-3841.15046

9. Corpet, D.E. (2021). Why does SARS-CoV-2 survive longer on plastic than on paper? Medical Hypotheses, 146,110429.

10. Cvijanović, D., \& Gajić, T. (2021). Development factor of rural areas in Serbia. Poljoprivrednik, Dnevnik Poljoprivrednik a.d. Novi Sad, CIP 63+39(059); ISSN 1450-5436, COBISS.SR-ID 11296007. 78-79.

11. Du Bois, D. (2020). Impact of the Coronavirus on global short-term rental markets. Retrieved https://www.airdna.co/blog/coronavirus-impact-on-global-short-termrental-markets. (Accessed 21 June 2020).

12. Dzwolak, W. (2014). HACCP in small food businesses - The Polish experience. Food Control, 36, 32-137. DOI: 10.1016/j.foodcont.2013.07.043.

13. Dzwolak, W. (2017). Assessment of food allergen management in small food facilities. Food Control, 73, 323-331. DOI: 10.1016/j.foodcont.2016.08.019.

14. Elgin, C., Basbug, G., \& Yalaman, A. (2020). Economic policy responses to a pandemic: developing the COVID-19 economic stimulus index. Covid Economics, 3, 40-53. 
15. Farzanegan, M. R., Gholipour, H. F., Feizi, M., Nunkoo, R., \& Andargoli, A. E. (2020). International tourism and outbreak of coronavirus (COVID-19): A crosscountry analysis. Journal of Travel Research, 60, 3, 687-692. DOI: https://doi. org/10.1177/0047287520931593.

16. FAO (2020). Food safety in the time of COVID-19, Rome, 1-6.

17. Fotiadis, A., Polyzos, B., \& Huan, T.C. (2021). The good, the bad and the ugly on COVID-19 tourism recovery. Annals of Tourism Research, 87, 103-117. DOI: doi: 10.1016/j.annals.2020.103117.

18. Gajić, T., Radovanović M., Tretiakova, T., \& Syromiatnikova, J. (2020a). Creating brand confidence to gastronomic consumers through social networks - a report from Novi Sad. Journal of Place Management and Development, 14(1), 32-42. DOI: https://doi.org/10.1108/JPMD-04-2020-0033

19. Gajić, T., Petrović, M.D., Radovanović M., Tretiakova, T.N., \& Syromiatnikov, J.A. (2020b). Possibilities of Turning Passive Rural Areas into Tourist Attractions Through Attained Service Quality. European Countryside Journal, 12(2), 179-276. DOI: https://doi.org/10.2478/euco-2020-0010.

20. Gajić, T., Vujko, A., Petrović, M.D., Mrkša, M., \& Penić, M. (2018). Examination of regional disparity in the level of tourist offer in rural clusters of Serbia. Economic of agriculture, 65(3), 911-929.

21. Garayoa, R., Díez-Leturia, M., Bes-Rastrollo, M., García-Jalón, I., \& Vitas, A.I. (2014). Catering services and HACCP: Temperature assessment and surface hygiene control before and after audits and a specific training session, Food Control, 43, 193-198. DOI: 10.1016/j.foodcont.2014.03.015.

22. Gibson, A., Edgar, J. D., Neville, C. E., Gilchrist, S. E., McKinley, M. C., \& Patterson, C. C. (2012). Effect of fruit and vegetable consumption on immune function in older people: A randomized controlled trial. American Journal of Clinical Nutrition, 96(6), 1429-1436. DOI: 10.3945/ajen.112.039057.

23. Gossling, S., Scott, D., \& Hall, C. M. (2020). Pandemics, tourism and global change: A rapid assessment of COVID-19. Journal of Sustainable Tourism, 29(1), 1-20. DOI: https://doi.org/10.1080/09669582.2020.1758708.

24. Guide 2020 edition - COVID-19 update. The HACCP 12 keys steps (and tips on how to implement it). A free guide for Quality Managers so as to help them develop their HACCP plan and manage efficiently all stages of the process.

25. Han, S., Roy, P.K., Hossain, M.I., Byun, K., \& Choi, C. (2021). COVID-19 pandemic crisis and food safety: Implications and inactivation strategies. Trends in Food Science and Technology, 109, 25-36. DOI: 10.1016/j.tifs.2021.01.004.

26. Hecht, A. A., Biehl, E., Barnett, D. J., \& Neff, R. A. (2019). Urban food supply chain resilience for crises threatening food security: A qualitative study. Journal of the Academy of Nutrition and Dietetics, 119(2), 211-224. DOI: https://doi. org/10.1016/j.jand.2018.09.001. 
27. Jawed, I., Tareen, F.R., Cauhan, K., \& Nayeem, M. (2020). Food safety and COVID-19: Limitations of HACCP and the way forward. Pharma Innovation, 9(5), 1-4. DOI: 10.3389/fmicb.2020.01854.

28. Kampf, G., Todt, D., Pfaender, S., \& Steinmann, E. (2020). Persistence of corona viruses on inanimate surfaces and their inactivation with biocidal agents. Journal of Hospital Infection, 104(3), 246-251. DOI: 10.1016/j.jhin.2020.01.022.

29. Lateefat, Sawyerr, H.O., Mubarakat, A., Yusuf, A.O., Yusuf, A.B., Opasola, O., Adedotun, A., \& Suleiman, U. (2018): Hazard Analysis Critical Control Point (HACCP) Assessment of Regulated Premises: An Assessment of Standard Hotels in Ilorin Metropolis. Journal of Health and Environmental Research, 4(2), 56-68. DOI: 10.11648/j.jher.20180402.13.

30. Lin, Q. Y., Zhao, S., Gao, D. Z., Lou, Y. J., Yang, S., Musa, S. S., Wang, M. H., Cai, Y. L., Wang, W. M., Yang, L., \& He, D. H. (2020). A conceptual model for the coronavirus disease 2019 (COVID-19) outbreak in Wuhan, China with individual reaction and governmental action. International Journal of Infectious Diseases, 93, 211-216. DOI: 10.1016/j.ijid.2020.02.058.

31. Official Gazette of RS ,72/2010 and 2/2018.

32. Official Gazette of RS, 41/2009 and 17/2019.

33. Olaimat, A. N., Shahbaz, H. M., Fatima, N., Munir, S., \& Holley, R. A. (2020). Food Safety During and After the Era of COVID-19 Pandemic. Frontiers in Microbiology, 11, 1854. DOI: https://doi.org/10.3389/fmicb.2020.01854.

34. Oliveira, C.A.F., da Cruz, A.G., Tavolaro, P., \& Corassin, C.H. (2016). Chapter 10 Food Safety: Good Manufacturing Practices (GMP), Sanitation Standard Operating Procedures (SSOP), Hazard Analysis and Critical Control Point (HACCP) in Antimicrobial Food Packaging, 129-139.

35. Pine, R., \& Mckercher, B. (2004). The impact of SARS on Hong Kong's tourism industry. International Journal of Contemporary Hospitality Management, 16(2), 139-143. DOI: 10.1108/09596110410520034.

36. Popov-Raljić, J., \& Blešić, I. (2012). Food safety - application of HACCP system in catering and hotel industry. University of Novi Sad, Faculty of Science, Department of Geography, Tourism and Hospitality, Novi Sad. 1-223.

37. Popov-Raljić, J., \& Blešić, I. (2016). Food safety - application of HACCP system in catering and hotel industry. Second revised edition. University of Novi Sad, Faculty of Science, Department of Geography, Tourism and Hospitality, Novi Sad. $1-223$.

38. Popov-Raljić, J., \& Blešić, I. (2021). Food safety HACCP system - theory and practice. Electronic edition. Singidunum University, Belgrade. 1-375.

39. Principato, L., Secondi, L., Cicatello, C., \& Mattia, G. (2021). Caring more about food: The unexpected positive effect of the Covid-19 ockdown on household food management and waste. Socio-Economic Planning Sciences.xxx(xxx)xxx. 
40. Qiu, R. T., Park, J., Li, S., \& Song, H. (2020). Social costs of tourism during the COVID-19 pandemic. Annals of Tourism Research, 84, 102994. DOI: 10.1016/j. annals.2020.102994.

41. Quevedo-Leon, R., Bastías-Montes, J. M., Espinoza-Tellez, T., Ronceros, B., Balic, I., \& Munoz, O. (2020). Inactivation of coronaviruses in food industry: The use of inorganic and organic disinfectants, ozone, and UV radiation. Scientia Agropecuaria, 11(2), 257-266. DOI: https: //doi.org/1 0.17268/ sci.agropecu. 2020.02.14.

42. Sharma, K.M. (2011). A Study of Food Allergy Awareness and Knowledge among Owners and Managers of Wellington. City Eating-houses. Food Technology, Massey University, New Zealand, 1-78.

43. Shi, M., Cheng, X., \& Zhang, X. (2021). Impacts of the COVID-19 pandemic on consumers' food safety knowledge and behavior in China. Journal of Integrative Agriculture, 19(12), 2926-2936. DOI: https://doi.org/10.1016/S20953119(20)63388-3.

44. Soon, J.M. (2018). Structural modelling of food allergen knowledge, attitude and practices among consumers in Malaysia. Food Research International, 111, 674681. DOI: 10.1016/j.foodres.2018.06.001.

45. Taylor, E. (2008). A new method of HACCP for the catering and food service industry. Food Control, 19, 126-134. DOI:10.1016/j.foodcont.2007.02.013

46. Trafialek, J., \& Kolanowski, W. (2017). Implementation and functioning of HACCP principles in certified and non-certified food businesses. British Food Journal, 119, 710-728. DOI : 10.1108/BFJ-07-2016-0313.

47. Xiang, M. Zhang, Z., \& Kuwara, K. (2020). Impacts of the COVID-19 pandemic on consumers' food safety knowledge and behavior in China. Journal of Integrative Agriculture, 19(12), 2926-2936. DOI: 10.1016/j.pcad.2020.04.013.

48. World Food Programme (2020). COVID-19 will double number of people facing food crises unless swift action is taken. 